\title{
Building partnering in construction under conditions of a new information space
}

\author{
Yury Shamara ${ }^{1,2}$, and Evgeny Smirnov ${ }^{1 *}$ \\ ${ }^{1}$ Saint Petersburg State University of Architecture and Civil Engineering, 190005 2-ya \\ Krasnoarmeiskaya st., 4, Russian Federation \\ 2 "KNGK-Group" Investment and Engineering Holding, 350000 Budennogo st. 117/1, Russian \\ Federation
}

\begin{abstract}
The analysis of institutional and technological prerequisites is given in this article to implement the partnering mechanism in the Russian building with respect to the declaration of the state policy for formation of the digital economy and adoption of the relevant strategy and state program. Three elements of information environment which are under formation at present and that can form a technological basis for the wide application of the mechanism of partnering in the investment and building process are identified as the reference ones: technologies for building information modeling, information analysis systems which unite various construction aspects in a single complex, and banks of regulatory documents and standard forms of contracts for use by building participants. It was concluded that the conditions for transition from the conventional models for implementation of the investment and building process to the models based on the building participants' partnership have been created in Russia.
\end{abstract}

Key words: partnering, investment and building project, digital environment, BIM technologies, partnering agreement

\section{Introduction}

A modern investment and construction project unites and contractually binds many participants of the investment and building process. In this case, the central, systemforming element of contract relations in framework of the project is a general contract as A. E. Churbanov aptly notes [1]. Formation of the unified information space and implementation of new digital technologies in the building will require to review production relations both in this branch, and in the economy as a whole that is discussed in the reports of the Organization for Economic Cooperation and Development published in $2016[2,3]$.

With historical hindsight, the building contract was primarily considered as a document establishing the "game rules" and sanctions for their violation: In this case, the contact parties are mainly represented as rivals, and their contract is the enforcement means to fulfill their obligations under the building project. However, since the 1990s of the past

\footnotetext{
*Corresponding author: pnr@spbgasu.ru
} 
century, the conceptual approach is increasingly being used in the foreign building practice according to which the participants of the investment and building project (IBP) are not considered as rivals, but, first of all, as partners progressing the same goal - project implementation. In this case, the building contract is represented less as the document where the game conditions and rules mandatory for observance by the Customer and Contractor, than as the document describing the conditions of the partnership between these two entities [4].

A significant number of studies abroad and a number of publications in Russia are devoted to the building partnership. The content of the partnership formed to implement the investment and building project is quite fully described in the paper of S. Børve, A. Rolstadås, I. Andersen and W. Aarseth [5], in the study of J. Bennett and A. Baird [6], as well as in the guidance papers of the Institution of Civil Engineers of the UK. This partnership means the following:

- open relationships that ensure transparency of pricing and project costs;

- joint management of project risks;

- mutual efforts for provision or improvement of preset project parameters;

- mutual efforts towards investor's cost cutout.

Chris Skeggs, summarizing the experience of partnering in the Australian building sector, points to the advantages of building partnering contracts in comparison with conventional ones: less disagreements and arbitrations, better characteristics of project results in terms of cost, time and quality, greater opportunities for saving the investor funds [7]. In support of the above mentioned, I. K. Pinkevich and E. B. Smirnov present a number of indicators obtained in Great Britain and that characterize the partnerships advantage over the conventional building contracts: increasing the ICP profitability by a mean of $25 \%$, reducing the building cost by $10 \%$, reducing the building time by $20 \%$ [8].

J. Bennett and S. L. Jayes point to extra costs as the partnership disadvantages; the partners bear these costs due to arrangement of cooperation at a higher (in comparison with normal construction contracts) level, a great number of meetings as well operation of a permanent coordinating body [9].

The papers of A. Howlett [11] and E. B. Smirnov [4] are devoted to the questions of building partnerships classification according to the conclusions of which the partnerships shall be classified as per three main characteristics: urgent or indefinite as per the nature of the partnership; a number of partners; the way of partnership documenting for.

Unfortunately, in the presence of a significant number of publications concerning the partnering between participants of the investment and building projects, insufficient attention is paid to assessment of a location and importance of information technology for the development and efficiency of these processes, while, according to the British Association of Building Products Manufacturers, the formation of national and regional information platforms in the field of building support will allow reducing investment costs by more than $30 \%$ [11]. As well as the study, the results of which are presented in the paper of W. Bouck [12], indicate the readiness of modern building for the transition to digital technology platforms. The analysis performed in 2013 by I. K. Pinkevich and E. B. Smirnov showed the conditions for implementation of partnering mechanisms in building practice starts to form in the Russian Federation, but this process is not quick due to insufficient support from the state and the professional community, and the absence of proper infrastructure [8]. The topic under consideration is actual in terms of the "Strategy of Information Society Development in the Russian Federation for 2017-2030" [13] and the state program "Digital Economy of the Russian Federation" [14] adopted in 2017, which provide the creation and development of the digital environment based on new business models, one of which can be a model of partnering between the participants of the investment and building process for the building sector. 
The purpose of this article is to assess the existing institutional and process prerequisites for implementation of the partnering mechanism in the Russian building sector including for the state needs.

In the state program "Digital Economy of the Russian Federation", the digital environment is understood as a set of interconnected information systems based on the relative process platforms. The digital environment for the building industry shall be considered as the one consisting of three elements:

1. The process platform based on the building information modeling technologies (BIM technologies).

2. Information and analytical systems that unite various building aspects in a single complex and are updated based on the incoming information on resources and external environment changes.

3. The regulatory documentation banks, standard projects, standard forms of contracts, etc. for application by the building participants.

Let's consider in detail the specified elements of the digital environment and their importance for the formation of the partnering mechanism.

\section{Information Modeling Technologies of Construction Objects}

The information model of a building or structure is defined as a shared resource of information about an object which basic function is to provide team operations of all concerned parties with the project throughout its full life cycle [15]. Let's compare this definition with the one of the building partnerships which:

- $\quad$ are open for all the participants of the investment and building project;

- cover all stages of the investment and building project: from the concept development to finishing building operations and handover the object to the Customer, and in some instances it includes the object operation stage including running and capital repairs, registration and renovation;

- provide complete procedural project performance.

Taking into account the above definitions, it is obvious that information modeling technologies, when applied in full, are an ideal process base to implement building partnering mechanisms. The problem is that now the use of information modeling technology in the Russian Federation is limited, mainly, to pre-design studies and building design, that is, it is not beyond CAD (computer-aided design systems) that were developed and used in the days of the Soviet Union. To create full information environment based on the object information model that can form the basis for partnership relations, the object information model shall be combined with information systems that ensure continuous receipt and processing of data from the external sources.

\section{National and Regional Information and Analytical Systems Used during Building}

According to the experts, at present in the country there are about four hundred federal state information systems and about a thousand regional ones representing data on suppliers, goods, services, prices, etc. [16]. Let's consider the most important of them in terms of providing the partnering conditions. 


\subsection{Unified Information System (UIS) in the Field of State and Municipal Procurements}

According to the experience of Commonwealth Nations, the partnerships have the greatest advantages over the conventional construction contracts when implementing projects in conditions of unstable financing, and those which are innovative, city-forming or emergency in nature. These include a significant number of construction projects for the state and municipal needs, which are often implemented in Russia in conditions of underfunding that reduces the effectiveness of relationships based on the commercial contracts, and where unformalized quasi-partnership relations are often formed spontaneously between the state customer and the contractor. It should be noted that the partnership does not contradict with the principle of competitiveness of public procurements, as partners are selected on a competitive basis like any other supplier of building activities and services. The analysis showed that in the Russian Federation as a whole there is the created institutional, process and information base that can provide competitive selection of partners in building projects for state needs including the following:

- unified information system in the field of public procurements;

- system of electronic platforms for electronic tenders;

- system of authorized organizations that provide the digital infrastructure functioning and are the centers of competence in this sphere.

The created digital environment can serve as a good basis for the wide implementation of partnering mechanisms in the building for public needs, but it will require a certain innovation to ensure the following:

- implementation of the "open book" principle;

- mechanism for joint management of project risks;

- the possibility of total package procurement contracts that integrate different types of operations at several stages of the investment and construction project.

\subsection{Unified Pricing Information Systems and Building Products Telemarketing Systems}

In December 2017, the Russian Federation introduced the federal government information system for building pricing (FGIS BP) that is intended to increase the reliability and transparency of building cost determination at all stages of the investment and building project. The FGIS BP focused on fixing the resource method of cost determination as the main method for building cost estimation and being one of the main peripheral interfaces of the building information models can provide ample opportunities for dynamic functionalcost analysis in the frameworks of partnerships to save investors' funds and increase the investment and building projects efficiency. The federal and regional pricing information systems are added by trade-information exchange-type systems, one of which is established in the Republic of Tatarstan. The analysis of the regional pilot project showed that the exchange mechanism allows removing the extra links in the procurement process, making the process of building costs forming as transparent as possible, and improving the calculations accuracy. 


\subsection{Other Information Systems and Data Bases}

The following can be presented as the examples of other information-analytical resources relevant to the study topic:

- urban development support information system (UDSIS) including a classified set of documented information on territories development, their construction, availability of land and other information required for the public authorities, local government authorities;

- the Unified State Register of Design Documentation Appraisal Reports of Capital Construction Objects (FAI Glavgosexpertiza of Russia);

- database of objects white tag created in accordance with Federal Law No. 261 "On energy saving and increase of energy efficiency";

- databases of technical and economic of buildings and structure certificates created in various cities of Russia.

The integration of information and analytical systems and databases into a unified information network and their integration in the building information modeling system is the most important prerequisite for the development of the building partnering mechanism of the Russian Federation.

\section{Regulatory Documents Banks, Development of Standard Contract Forms for Partnering Application}

The partnership represents a new model of relationship for Russia between the participants of the investment and building process, and therefore it requires the proper provision of regulatory, methodological and contractual documentation. The partnership can be documented by inclusion a unified additional section describing the partnering terms obligatory for all participants in all contracts awarded under the building project. This method is implemented as a series of model building contracts NEC (New Engineering Contract) developed by the Institute of Civil Engineers of Great Britain (ICE) for application in national and international building projects [17]. The second way of partnering registration provides for the conclusion of the investment and building project of a separate multilateral partnership agreement by the participants that is complementary relative to the awarded bilateral contracts, or completely replacing them. Such an agreement should be open so that, while progressing the project, all of its key participants: the customer, the designer, the general contractor, the technical consultants, and the most important suppliers can be involved. A partnership agreement of this type provides for establishing a coordinating body, which includes the representatives of all partners. The model partnering agreement can be given as the example for application in building projects PPC 2000 (Project Partnering Contract 2000) issued in 2000 by the British National Association of Consulting Engineers [18].

The performed analysis showed that the absence of regulatory, methodological and contractual support of partnerships is currently the main obstacle to implement the partnering model in the building of Russia. 


\section{Conclusions}

The creation of the institutional and technological base is under completion in the Russian Federation, and it generates the unified information space in the building sector creating the prerequisites for a transition from the conventional models of the investment and building process implementation to models based on the partnership of building participants.

The partnership will be developed based on the information environment generated with the support of concerned public authorities, and that is based on the process platform of the building information modeling integrated with the federal, regional and corporate information and analytical systems, databases and information banks, which will ensure continuity, continuity and high efficiency of management under a dynamically changing environment during a full life cycle of objects.

For the successful implementation of partnering mechanisms in building practice, the state and the professional community shall pay the attention to development of legislation, methodological support and preparation of the standard documentation including standard forms of partnering agreements, and generation of the interaction and experience exchange system in this field.

\section{References}

1. A. E. Churbanov, Generation of contracting relations in modern building (SaintPetersburg State University of Engineering and Economics, St. Petersburg, 2006)

2. OECD, OECD Digital Economy Papers, 260 (2016)

3. OECD, OECD Digital Economy Papers, 256 (2016)

4. E. B. Smirnov, Civil Engineers Bulletin, 2 (2012)

5. S. Børve, A. Rolstadås, B. Andersen, W. Aarseth, International Journal of Managing Projects in Business, 10(4) (2017)

6. A. Baird, J. Bennett, NEC and Partnering: A Guide to Building Winning Teams (Thomas Telford, London, 2001)

7. C. Skeggs, Project Partnering in the International Construction Industry (Abigroup Contractors, Sydney, 2000)

8. I. K. Pinkevich, E. B. Smirnov, Modern economic problems, 4 (48) (2013)

9. J. Bennett, S. L. Jayes, Seven Pillars of Partnering: A Guide to Second Generation Partnering (Thomas Telford, London, 1998)

10. A. Howlett, International Construction Developments-What Comes After Partnering [online], Available at: http:// wwwljonesday.com/practices/puLdetail (2002)

11. The Future for Construction Product Manufacturing Digitalization, Industry 4.0 and the Circular Economy. Report (October 2016) by Construction Products Association, London [online], Available at: https://www.thefis.org/wp-content/uploads/2016/10/cpafuture-of-construction-product-manufacturing-report-2016.pdf(2016)

12. W. Bouck, Mapping the Information Economy: A Tale of Five Industries [online], Available at: https://blog.box.com/blog/mapping-the-information-economy-a-tale-offive-industries (2014)

13. Decree of the President of the Russian Federation, 203 dated 09.05.2017 "On the Strategy of Information Society Development in the Russian Federation for 20172030" [online], Available at: http://kremlin.ru/acts/bank/41919 (2017) 
14. Regulation of the Russian Federation Government No. 1632-p dated July 28, 2017 "On approval of the program "Digital Economy of the Russian Federation" [online], Available at: http://base.garant.ru/71734878/ (2017)

15. National BIM Standard - United States. National Institute of Building Sciences [online], Available at: https://www.nationalbimstandard.org/files/NBIMSUS_FactSheet_2015.pdf (2015)

16. A. P. Dobrynin, K. Yu. Chenykh, V. P. Kupriyanovsky, P. V. Kupriyanovsky, S. A. Sinyagov, International Journal of Open Information Technologies, (4) 1 (2016)

17. The NEC Partnering Option: First Edition, June 2001 (Thomas Telford Limited, Heron Quay, London, 2003)

18. Standard Forms of Contract for Project Partnering (Trowers \& Hamlins, London, 2005)

19. W. Bouck, Mapping the Information Economy: A Tale of Five Industries [online], Available at: https://blog.box.com/blog/mapping-the-information-economy-a-tale-offive-industries (2014) 